extents of arable cultivation and grassland within each primary vegetation type are also indicated. The associations shown are for the most part forest types, the twenty-two symbols representing dominants all referring to trees and shrubs. The maps are thus particularly valuable as showing at a glance the types and detailed distributions of woodlands and their relation to topographical features and geographical location. The utility of these finely printed maps to botanical visitors will be considerable, though placenames are not easy to decipher beneath the superimposed colours and symbols. The legends and keys are given in French and German, and each map measures $37 \mathrm{in}$. by $26 \frac{1}{2} \mathrm{in}$. They are printed on stiff paper by Kummerly and Frey of Bern and are obtainable from Hans Huber of Bern at a cost of 12 Swigs francs each.

\section{Ancient Fishing on the River Severn}

THE interest in folk museums is growing throughout Great Britain. Th ere those who would like to see inamens buas set aside for folk studies on a nofianal scale on the Scandinavian plan, whereas others are content with more regional establishments, even down to a county basis; but no folk museum of any kind will be of the slightest value unless its collections provoke study and subsequent pub. lication. It is for this reason that a modest little work, "Guide to the Severn Fishery Collections", by J. Neufville Taylor, which has been published by the City of Gloucester Folk Museum, is to be commended, and it is to be hoped there will be many more like it. The various methods used on the River Severn to catch the difierent fish required will also be of interest to fishermen, even to those who despise all methods except bat of the rod, fly and line.

\section{The Europeap Bison}

Is recent thers, the Society for the Preservation of the Forpa of the Empire has taken keen interest in the fiorts made by the International Society for the Preservation of the Wisent [European bison] to save this remarkable relative and possibly forbear of the American bison from extinction. Its ultimate survival is still open to doubt and, in the July issue of the Journal of the Society for the Preservation of the Fauna of the Empire, is assembled the latest information procurable on the status of the species. Frof. Jan Zabinski and Miss Erna Mohr contribute authoritative articles from difierent points of view, and these are prefaced by extracts from a recent paper of Nir. Richard Glover's which both sum. marizes the known history of the wisent and deals with its contrasts to and similarities with the American bison. If suitable action is taken, there seems to be reasonable hope that the wisent may survive under protection in the right conditions of forest space to bring its numbers up to those which existgd before the First World War.

\section{The Mo!luscan Stomach}

Is continuation of hiovstudies on the alimentary canal of Mplusca, Pfof. A. Graham has described the stomach of tyrigl lamellibranchs and prosobranch getstropgs, elscussed the functions and homplugies of he parts and compared them with thdse of the Polyplacophora and Cephalopoda ("The Molluscan Stomach", by Alastair Graham. Trans. Roy. Soc. Edin., 61, Part 3, No. 27 ; 1949). The molluscs considered range from the ciliaryfeeding microphagous lamellibranchs to the browsing macrophagous gastropods; but only to the more primitive members of the latter class, which exhibit, at least in the trochids, a close resemblance to the lamellibranch type of stomach, with its style sac, major and minor typhlosoles, cecum, grooved sorting area and gastric shield. A simplification of this structure is to be expected in carnivorous gastropods, and does, in fact; occur. One effect of torsion on the primitive form of the stomach is the displacement of the œesophagus from an anterior to a posterior position, so that eventually, in tectibranchs and pulmonates, the œsophageal and intestinal openings are adjacent to one another, and as a result the stomach itself becomes a cæcum receiving the ducts of the digestive gland. The stomach of Patella is peculiar in that it is small, ill-defined and devoid of a cæcum or gastric shield, but it possesses two typhlosoles. The paper is illustrated by twenty-three figures of outstanding merit, prepared by a skilled use of scraper board combined with mechanical stippling.

The Backward Adulton In the latest of ${ }^{2}$ series of articles in Army Education
23, No. 2 , the 1949), Dr. W. D. Wall describes the case studiesthe has made with backward men. His inguirles with adults are supported by investigations wich have been made with groups of backward children in schools and show that the majority of the educationally retarded are below the general level of the population in intelligence; any group of poor readers is likely to contain between a half and two. thirds of men whose level of intelligence is sub. normal. On the other hand, there are many nearilliterates whose mental level is nearly normal or even supernormal. Some of these often have difficulty in distinguishing the shapes of similar letters like $b$ and $d, m$ and $n, p$ and $q$. In other cases there is a tendency to reversals, either of single letters or of words, showing that the habit of attacking a word from left to right is not established. Some backward adults of average intelligence have marked difficulties in recalling material presented aurally or visually, or in synthesizing into whole words syllables which can visually or auditorily be discriminated quite well. A third class of defects is physiological, and, in a group of a hundred backward readers studied by Wall, defects of hearing and vision were nearly twice as frequent as among a group of normal readers of otherwise comparable background. Speech defects--stammering, lisping and marked hesitations accompanied by disturbance of breathing - and lefthandedness or a tendency towards it also seem to operate as handicaps in learning. The factor which, apart from intelligence, is of greatest significance in leading to backwardness is that of personal adjustment. In Wall's inquiries nearly two-thirds of the men showed that they were not adjusting themselves to the demands of even a relatively simple existence. It is, however, difficult to estimate how far emotional disturbances during and after school life inhibit learning and how far educational failure contributes to adult maladjustment.

\section{Measuring Prodorictivity}

The 1848 49 Winter Proceedings of the British Instipute of Management have been presented as a ryport. The fourth meeting was addressed by Sir Ewart Sintth and Dr. R. Beeching who, in a joint paper, discussed the means of measuring the effectiveness of the productive unit. After defining the meaning of 
productivity, the authors elaborate the factors affecting it and the problems of measurement. To arrive at a true measure of effectiveness, it is necessary to make allowance not only for the number of personnel engaged in the unit under examination but also for the invisible men who serve the unit externally in the supply of the necessary capital equipment, raw materials and other services. Sir Ewart and Dr. Beeching also consider that Marshall Aid distorts the productivity picture. The present rate of this aid is equivalent to the wages of 750,000 industrial workers at current British wage rates, and since "the total number engaged in industrial production in Gt. Britain is some $10,500,000$, Marshall Aid is equivalent to an increase in our industrial production of 7 per cent as a first approximation". Among points which arose in discussion were the problem of plant valuation and the need for individual firms to give more thought to the question of labour incorporated in capital equipment. The report may be obtained from the British Institute of Management, 17 Hill Street, Londgn, W.1, price $2 s$. $6 d$.

\section{Abstracting Journals}

A List of Periodicals and Bulletins containing abstracts published in Great Britain has been prepared under the supervision of the Abstracting Services Cofiph tative Committee and issued by the Royal Sociej (London: Camb. Univ. Press. Pp. 62. 2s. 6 A. NCh periodicals are listed alphabetically by tick win explanatory notes, and there is a further cfas lifiod list under the following heads: agriculture, bdtany, food and nutrition; biology; chemistry, chemical industry and mineralogy; engineering; electrical engineering; medicine; metallurgy ; miscellaneous industries; physics, geology and meteorology. An index to the names of institutions, societies and other publishers is included, and a partial list of journals containing abstracts published in the British Commonwealth is appended. Information on omissions, particularly of abstracting bulletins of industrial concerns, is invited, for possible incorporation in future editions.

\section{Institution of Naval Architects: Awards}

THE Institution of Naval Architects has recently announced the following awards for 1949: 1851 Exhibition commissioners postgraduate research scholarshio in naval architecture ( $\$ 500$ per annum for two years) to I. M. Yuille, University of Glasgow ; Aluminium Development Association research schglarship in the application of light alloys to ship construction ( $£ 400$ per annum for two years) to J. B. Caldwell; Martell scholarship in naval architecture (£175 per annum for three years at the Royal Naval College, Greenwich) to J. W. Goymer, H.M. Dockyard, Sheerness ; Earl of Durham prize, in connexion with the examination for the Martell scholarship in naval architecture, to S. Faulkner, H.M. Dockyard, Devonport.

\section{Awards of National Certificates in Textiles \\ OF a total of 298 students who took the examina.} tions this year for the award of national certificates in textile\%, 230 students were successful, 157 having studied cotton subjects and 73 woollen and worsted processing. This is the highest number of successes so far obtained since the inception in 1935 by the Textile Institute and the Ministry of Education of the scheme for the award of certificates. The corresponding number last year was 195, and the highest pre- war total was 186. The awards this year are divided as follows: for the ordinary national certificate, 205 candidates sat and 150 secured awards ; of 93 students seeking the higher national certificate, 80 were successful. The former certificate entails three years of study and the latter five years.

\section{Announcements}

Prof. W. L. WAterhouse, research professor of plant pathology and agricultural botany in the University of Sydney, has been awarded the Farrer Memorial Medal for 1949 in recognition of his work on yheat diseases and their control.

THE Lord President of the Council has appointed the following to the Advisory Council for Seientific and Indust ial Research for five years from October 1 , 1949 : Mr. A. H. Wilson, since 1945 director of researy and development of Messrs. Courtaulds, Ltd.; Mr. A. H. S. Hinchliffe, governing director of Glazebrook Steel and Co., cloth merchants and exporters, of Manchester; Lord Halsbury, managing director of the National Research Development Council ; and Prof. R. S. Edwards, of the London School of Economics, who has recently made a comprehensive study of research associations. The new members succeed Mr. W. F. Lutyens, Mr. W. J. Drummond, Sir Henry Guy and Sir William Halcrow, who have retired on the completion of their appointments.

Mr. N. A. W. LE GRand, until recently secretary and coymercial administrator of Messrs. J. D. P. Whegtley and Co., has been appointed secretary of the British Welding Research Association, in succession to Mr. A. Barker, who has joined the staff of the British Boot and Shoe Manufacturers' Association.

UNDER the auspices of the Linnean Society of London/in conjunction with the Systematics Association, a course of lectures and demonstrations on "The Practice of Botanical and Zoological Classification" will be given in the rooms of the Linnean Society, Burlington House, London, W.1, on the following dates: October 26, November 9, 23, January 25, February 8, 22, March 8 and May 6. The meetings, which are open to advanced students of biology, will begin at 4.30 p.m.

APPROXIM pele thirty-one post-doctorate fellowships will be offered by the National Research Council of Canada for the year 1950-51, eighteen of which will bo awarded in chemistry, three in atomic energy resparch, and about ten in physics. The stipend is 2.820 dollars per annum, tax free, and is supplemented by travel grants for successful candidates from abroad. While appointments at the Atomic Energy Project, Chalk River, are restricted to Canadian citizens and British subjects, applicants of all nationalities are invited for the Divisions of Chemistry and Physics. Application forms (to be received in Ottawa not later than February 15, 1950) can be obtained from the Secretary, Laboratories Awards Committee, National Research Council, Ottawa, Canada, or from the Chief Seientific Liaison Officer, National Research Council of Canada, Africa House, Kingsway, London, W.C.2, England.

Erray JM. In Nature of October 8, p. 606, Prof. S. Zugkerman was incorrectly described as professor of ghatomy and physiology in the University of Bitmingham. Prof. Zuckerman is professor of anatomy; the professor of physiology is Prof. H. P. Gilding. 